\title{
Effects of Speed on Draft for Selected Tractor-Driven Tillage Implements in Samaru Soil, Zaria, Nigeria
}

\author{
*SALEH, A; SANI, MT; SULEIMAN, ML \\ Department of Agricultural and Bio-Resources Engineering, Ahmadu Bello University, P.M.B. 1044, Zaria, Nigeria \\ *Corresponding Author Email: salehaminu@gmail.com; Tel: +234803 5774780
}

\begin{abstract}
The objective of this study was to determine the effects of speed on drafts of some selected tractordriven tillage implements in Samaru soil in order to address the problem of inadequacy of local design data, inappropriateness and inadaptability of such imported implements. Three tillage implements were used at three tractor speeds on the field at three tillage depths using two Eicher tractors (5660). The draft forces replicated, three times, were measured using dynamometer. Soil samples collected from different points in the field were analyzed for moisture content (MC), humus content and bulk density (BD). The results showed that draft of the three implements were related to the speed of the tractor. Result obtained also showed MC varies from $8.40-15.11 \%$, BD varies from $1.62-1.77 \mathrm{~g} / \mathrm{cm}^{3}$ and humus content from 4.207-0.625\% down the soil profile. At the lowest MC of $8.40 \%$, drafts of $3.07,5.13$ and $9.33 \mathrm{kN}$ at speed $2.5 \mathrm{~m} / \mathrm{s}$ were obtained for the selected implements. Drafts of 2.00, 2.80 and $4.03 \mathrm{kN}$ were obtained at the highest MC of $15.11 \%$ at $2.5 \mathrm{~m} / \mathrm{s}$ speed. It is clear from the experiment that draft increases with increase in speed for disc plough, disc harrow, tillage depths and BD, while draft decreases with increase in $\mathrm{MC}$ and speed of mouldboard ridger. The best speed for tillage is $2.5 \mathrm{~m} / \mathrm{s}$ obtained at optimum MC $10.67-15.11 \%$ for soil under consideration. Disc plough requires highest draft $2.8-9.33 \mathrm{kN}$ followed by mouldboard ridger $4.03-5.83 \mathrm{kN}$ and disc harrow requires least draft $2.0-3.57 \mathrm{kN}$ at each of the three speeds considered.
\end{abstract}

DOI: https://dx.doi.org/10.4314/jasem.v25i5.9

Copyright: Copyright $\left({ }_{0} 2021\right.$ Saleh et al. This is an open access article distributed under the Creative Commons Attribution License (CCL), which permits unrestricted use, distribution, and reproduction in any medium, provided the original work is properly cited.

Dates: Received: 20 March 2021; Revised: 27 April 2021; Accepted: 07 May 2021

Keywords: Speed, Draft, Implements, Tillage, Soil

The first operation the farmer has to undertake in growing a crop is to use a soil engaging implement to prepare the soil (Kawuyo, 2011). Hunt (1979) reported that proper selection and matching agricultural machines could reduce the amount of energy required for each implement. Field efficiencies and capacities are key parameters for evaluating agricultural machine performance. According to Abdallah et al. (2017), performance data for chisel plough operation is essential in order to optimize its performance and reduce the cost of tillage operation. Adjustments should be made from time to time because there are variations in the soil (USDA, 1984). To enhance the production of crops, the use of machines becomes important for suitable soil conditions, seed germination and plant growth. In selecting suitable tillage implements for a particular farm operation, draft power requirement data is an important factor. Draft power requirement of each soil type differs, hence operational implement tests should be conducted on each soil type. Farm managers and consultants could only make informed and sound decisions on selection of tractors and implements based on their performance parameters. Proper selection and matching of implement onto the tractor is essential to reduce operational cost and this would also ensure efficient farm machinery use. Implement specifications, such as effective working width, working depth and operational forward speed affect draft power requirement significantly. Draft is also affected by soil condition such as the soil moisture content, clay content and soil hardness (Agrimoon, 2016). The existing data on the effect of speed on draft are inadequate and limited for Samaru soils, \{Majid $e t$ al. (2013), Nkakini (2015), Omofunmi et al. (2016), Abdallah et al. (2017), and Lakadri (2017)\}. This caused frequent breakdown of locally fabricated tillage machines and inadaptability of imported ones designed using data from external locations. Although many studies have been conducted on different draught characteristics such as speed of operation, depth of cut in many parts of the world, there is little information on these subject for Nigerian conditions in general and upland soils of Samaru in particular. This study, therefore, was aimed at investigating the effects of speed on draft for three selected tractor-powered tillage implements: Disc Plough, Disc Harrow and Mouldboard Ridger to suit the local soil conditions particularly in Samaru, Zaria and Nigeria at large. 


\section{MATERIALS AND METHODS}

Experimental site: The experiment was conducted at the Research Farm of the Department of Agricultural and Bio-Resources, Ahmadu Bello University, Samaru-Zaria. Samaru is located on latitude $112^{0} 12^{\text {" }}$ $\mathrm{N}$, longitude $07^{0} 37^{\prime \prime} \mathrm{E}$ and an altitude of 550-700 metres. Samaru evolved from a small colonial farming settlement to become a large community that is often referred to as "University village". It is cosmopolitan in nature, drawing and fusing people of divergent national and international backgrounds. Generally, Zaria is characterized by gentle rolling plains dotted with groups of rocky residual hills developed on granite bedrock (ABU, 2018).

Study tractors and tillage implements: Two Eicher (5660) tractors were used for the study. One of the tractors served as testing tractor with implements attached to its three point linkage, while the other tractor served as an auxiliary tractor pulling the testing tractor through the dynamometer. The specifications of the tractors are: 3-Cylinders, 4-Strokes, maximum speed of $33.8 \mathrm{~km} / \mathrm{h}, 540 \mathrm{rpm}$ PTO shaft, direct water cooling, $50 \mathrm{hp}\left(37.285 \mathrm{~kW}, 3300 \mathrm{~cm}^{3}\right.$ engine), lift up to $1470 \mathrm{Kg}$, and has 8 forward and 2 reverse gearboxes with disk brake and oil immersed brake.

Two-bottom tractor-drawn disc plough with $64 \mathrm{~cm}$ disc diameters, offset disc harrow with $45 \mathrm{~cm}$ disc diameter and three-bottom Mouldboard ridger with 68 $\mathrm{cm}$ width of cut were used for the study (Plate I). The disc plough has a thrust wheel attached to it. The implements are representative of the standard land preparation (tillage) tools commonly used in the study area.

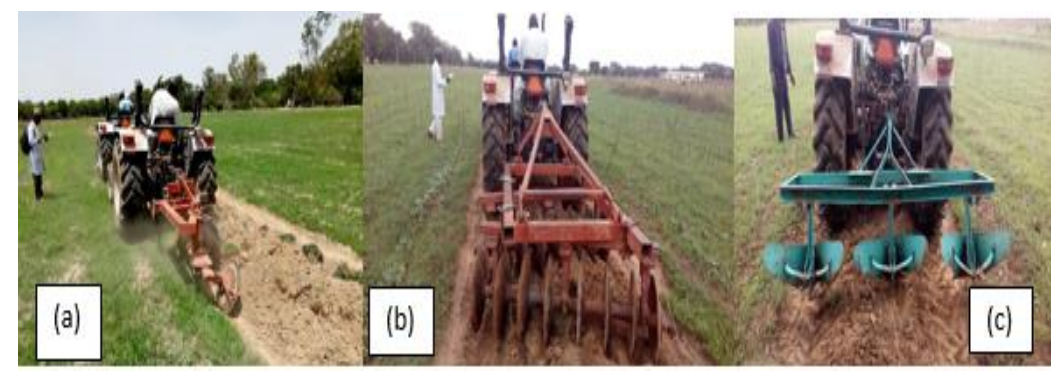

Plate I: Implements used for the study: (a) Two-bottom disc plough (b) Offset disc harrow, (c) Mouldboard ridger

Other materials used for the study are:

Dynamometer ((HP-100 Digital; $20 \mathrm{kN}$ capacity) used to determine the draft of the implement by registering the pull or draft of the implement and measure the power output of an engine over a measured distance (Robert, 2016). It has a size range of $0.2-20 \mathrm{kN}$.

Measuring tape - Steel measuring tape of $30 \mathrm{~m}$ long size was used for distance measurements in the field.

Metre rule - Steel metre rule of $30 \mathrm{~cm}$ long was used for depth measurements during the experiment. It measures the depths of cut from the bottom of the furrow to the surface level of the soil at randomly selected points.

Wooden pegs - used for marking starting and ending points in the field.

Steel Cable - used because of its rigidity to couple the testing tractor to the auxiliary tractor through the dynamometer.

Recording apparatus - labelled sheet of papers and a biro were used for recording the draft at appropriate times. A digital camera for taking pictures and video clips were used during the experiment to ensure adequate record keeping.

Soil sampling apparatus - Ten steel core samplers and twelve polythene bags were used to collect the soil samples at various depths during each experiment, absolute care was taken to prevent moisture loss through evaporation.

Methods: Draft force developed by the tractor at three various speeds $[1.5 \mathrm{~m} / \mathrm{s}(5.4 \mathrm{~km} / \mathrm{h}) ; 2.0 \mathrm{~m} / \mathrm{s}(7.2 \mathrm{~km} / \mathrm{h})$ and $2.5 \mathrm{~m} / \mathrm{s}(9 \mathrm{~km} / \mathrm{h})]$ attached with the tillage implements were measured with the dynamometer. The speeds are selected according to ASAE (2000). The testing tractor was attached to the tillage implements via three point linkage which in turn was connected to the pulling tractor through the dynamometer using a Steel Cable. The draft force developed at the drawbar (Eqn. 1) could be measured for the series of speed values used, USDA (1984).

$D B P=D r a w$ bar pull $(k N) \times \operatorname{speed}\left(\frac{m}{s}\right) k w .$.

Experimental design: A $3 \times 3 \times 3$ factorial experiment arranged in a Randomized Complete Block Design (RCBD) in three replicates was used. An experimental 
area of $9000 \mathrm{~m}^{2}$ (180 m by $\left.50 \mathrm{~m}\right)$ was selected. Each replicate has $3000 \mathrm{~m}^{2}(60 \mathrm{~m}$ by $50 \mathrm{~m})$ area. The experimental treatments consist of three speeds $\left(\mathrm{S}_{1}=\right.$ $\left.1.5 \mathrm{~m} / \mathrm{s}, \mathrm{S}_{2}=2.0 \mathrm{~m} / \mathrm{s}, \mathrm{S}_{3}=2.5 \mathrm{~m} / \mathrm{s}\right)$, three tillage depths $\left(\mathrm{d}_{1}=5-10 \mathrm{~cm}, \mathrm{~d}_{2}=10-15 \mathrm{~cm}, \mathrm{~d}_{3}=15-20 \mathrm{~cm}\right)$ and three tillage implements $\left(\mathrm{I}_{1}=\right.$ Disc Plough, $\mathrm{I}_{2}=$ Disc Harrow, $\mathrm{I}_{3}=$ Mouldboard Ridger).

Measurements of Draft: Spring-type dynamometer ((HP-100 Digital) of $20 \mathrm{kN}$ capacity was linked to the front of one of the two Eicher tractors (testing tractor) on which the implement was mounted during the experiment. The second tractor (auxiliary tractor) was connected to the testing tractor through the dynamometer. The auxiliary tractor pulled the testing tractor while the testing tractor was positioned in the neutral state without the implement. Draft values were recorded as indicated by the dynamometer readings without implement $(\mathrm{Du})$ for the three speeds for a distance of $60 \mathrm{~m}$ each $\left(\mathrm{Du}_{1}, \mathrm{Du}_{2}\right.$, and $\left.\mathrm{Du}_{3}\right)$.

The implements (disc plough first, followed by disc harrow and lastly mouldboard ridger) were mounted one after the other on the testing tractor. It was pulled by the auxiliary tractor and the draft values (Dm) as indicated by the dynamometer reading were recorded for each trial. The difference between the two readings of the dynamometer $(\mathrm{Dm}-\mathrm{Du})$ gave the value of the actual draft of the implement in each case. The above steps were repeated for speeds $S_{1}, S_{2}$ and $S_{3}$ and each speed was used for the three tillage depths $d_{1}, d_{2}$ and $d_{3}$. Draft force was calculated as follows:

$$
D=D_{m}-D_{u}
$$

Where: $\mathrm{D}=$ Actual Implement Draft; $D_{m}=$ Draft of tractor with mounted implement; $D_{u}=$ Draft of tractor without mounted implement

The procedure was replicated three times and the average draft was calculated for each treatment. Drawbar power was calculated after draft measurement as:

$$
D M P=\frac{\left[\operatorname{Draft}(k N) \times \text { Speed }\left(\frac{k m}{h}\right)\right]}{3.6}(\mathrm{~kW}
$$

Soil sampling and analysis: Soil samples were collected from the exposed soil at $5-10 \mathrm{~cm}, 10-15$ $\mathrm{cm}$ and $15-20 \mathrm{~cm}$ depth. After ploughing, coresamplers were used to collect samples while samples were collected with an excavator after harrowing and ridging. Samples collected were analyzed in Processing Laboratory of the Department of Agricultural and Bio-Resources Engineering of the university to determine the soil moisture content and bulk density. Similarly, humus content, soil texture and particle size distribution (Sand, Silt and Clay) were determined in the Department of Soil Science, Ahmadu Bello University.

Soil Moisture Content and Bulk Density Determination: The bulk density and moisture content of the soil were determined in Processing Laboratory of Agricultural and Bio-Resources Engineering Department, Ahmadu Bello University as outlined by Kawuyo, (2011):

$$
\begin{array}{rl}
M_{c}(\%)=\frac{W 2}{W 3}-W 3 & W 1 \\
M_{c}(\text { wet basis }) & =\frac{W w-W d}{W d} \times 100 \\
& =\frac{W m}{W d} \times 100
\end{array}
$$

Volume of core-sampler (v) $=\frac{\pi \times d^{2}}{4} \times h$; Mass of Oven dried soil sample $(\mathrm{M})=\mathrm{W} 2-\mathrm{W} 3$

$$
\text { Bulk Density }\left(D_{b}\right)=\frac{M}{V}
$$

Statistical Analysis: The data obtained were analyzed using descriptive statistics and SAS while linear regression analysis and analysis of variance (ANOVA) were used to draw inferences and interactions among variables.

\section{RESULTS AND DISCUSSIONS}

The results obtained from the soil analysis showed that the amount of sand, silt and clay vary in their proportions (Table 1). Sand fraction constituted high percentage $(52 \%)$ of the soil. This result was confirmed by the observation of Kawuyo (2011) on Samaru Savannah zone soils and on upland soils of Samaru but disagreed with the findings of Mohammed (2014) on Samaru soil. The results also showed that Samaru soils are good for optimum plant growth as earlier observed by Chandrasekaran (2010).

There was no considerable variation in the soil components down the soil profile $(0-20 \mathrm{~cm})$ : silt percentage remained constant in all the three depths considered. Clay and sand percentages slightly varied by $2 \%$ at depth range of $10-15 \mathrm{~cm}$. This might be as a result of previous cultivation on the soil, which caused the transported sand sediments to be moved into the deeper soil profile while the compacted inner layer was brought to the surface due to soil inversion. The clay and sand fractions remained constant over the other two depth profiles. 


\begin{tabular}{|c|c|c|c|c|c|c|c|c|}
\hline $\begin{array}{l}\text { Depth } \\
\text { (cm) }\end{array}$ & $\begin{array}{l}\text { MC }(\% \\
\text { w.b. }) \text { after } \\
\text { ploughing }\end{array}$ & $\begin{array}{l}\text { MC }(\% \text { w.b. }) \\
\text { after harrowing } \\
\text { and ridging }\end{array}$ & $\begin{array}{l}\text { BD } \\
\left(\mathbf{M g} / \mathbf{m}^{3}\right)\end{array}$ & $\begin{array}{l}\text { OM } \\
\text { Content } \\
(\% \text { w.b })\end{array}$ & $\begin{array}{l}\% \\
\text { Clay }\end{array}$ & $\begin{array}{l}\% \\
\text { Silt }\end{array}$ & $\begin{array}{l}\% \\
\text { Sand }\end{array}$ & $\begin{array}{l}\text { Textural } \\
\text { Class }\end{array}$ \\
\hline $5-10$ & 8.40 & 9.67 & 1.62 & 4.21 & 10 & 38 & 52 & Loam \\
\hline $10-15$ & 9.02 & 10.62 & 1.63 & 1.66 & 8 & 38 & 54 & Sandy Loam \\
\hline $15-20$ & 10.11 & 15.11 & 1.77 & 0.65 & 10 & 38 & 52 & Loam \\
\hline
\end{tabular}

The soil organic matter investigated in this study decreases with increase in depth of soil profile as shown in Table 1. Similar observations were reported by Kawuyo (2011). The $5-10 \mathrm{~cm}$ depth profile has $4.21 \%$ of organic matter content, while the corresponding values for $10-15 \mathrm{~cm}$ and $15-20 \mathrm{~cm}$ depths profiles were $1.66 \%$ and $0.65 \%$ respectively. This indicates that the soil is rich in organic matter content compared to the results of Kawuyo (2011) who reported that a soil profile between $0-15 \mathrm{~cm}$ depths with $1.18-1.26 \%$ organic matter has moderate level of organic matter content. The soil is, therefore, very good for plants development.

Effects of Draft on Tillage Implements at various Speeds and Depths: Results obtained shows that the relation between speed of tractor and draft of disc plough is linear particularly at depths $5-10 \mathrm{~cm}$ and 15 $-20 \mathrm{~cm}$. There is slight increment in depths $10-15 \mathrm{~cm}$ which may be attributed to change in soil strata during the previous tillage operations on the soil (Figure 1). There was significant increase in draft as the speed increases: at depth $\mathrm{d}_{1}$, increase of draft of $64.3 \%$ from $S_{1}$ to $S_{2}$ and $38.5 \%$ from $S_{2}$ to $S_{3}$, while increase in draft of $26.9 \%$ from $S_{1}$ to $S_{2}$ and $18.6 \%$ from $S_{2}$ to $S_{3}$ at $d_{3}$ were observed. This result agrees with the reports by Naderloo (2014) and Nkakini (2015). Similar observation was reported on the upland soil of Samaru, by Kawuyo (2011) and Majid et al. (2013). The linear regression analysis performed revealed that the relationships between speed and draft of disc plough (eqn. 2) was shown in Figure 1. It could therefore be seen that, when a farm manager decides the depth of tillage, say $15 \mathrm{~cm}$, and the speed of operation, say 7.2 $\mathrm{km} / \mathrm{h}(2.0 \mathrm{~m} / \mathrm{s})$ of a particular implement, say plough, the data in Figure 2 is sufficient to determine the size of the tractor power required. The drawbar power (DBP) was determined (eqn. 3) as $13.62 \mathrm{~kW}(18.26$ hp). This implies that, tractor with medium hp should be used. Higher size tractor would waste energy while lower size tractor would be inadequate to operate the implement. The draft of disc plough increases and varies almost linearly with increase in tillage depth at speed $5.4 \mathrm{~km} / \mathrm{h}$ or $1.5 \mathrm{~m} / \mathrm{s}$ of tractor (Figure 2). Increase in draft of $40.4 \%$ from $\mathrm{d}_{1}$ to $\mathrm{d}_{2}$ and $57.8 \%$ from $d_{2}$ to $d_{3}$ were recorded. Slight drift that could be seen at $10-15 \mathrm{~cm}\left(\mathrm{~d}_{2}\right)$ depth may be caused due to change in textural make-up of the soil from loam to sandy loam.

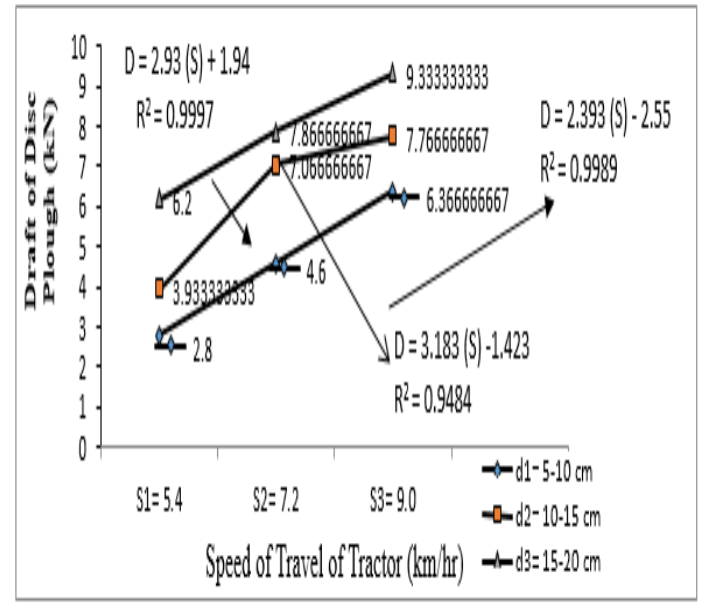

Fig 1: Effect of Speed (S) on Draft Force (D) of Disc Plough at Various Tillage Depths in Samaru loamy Soil

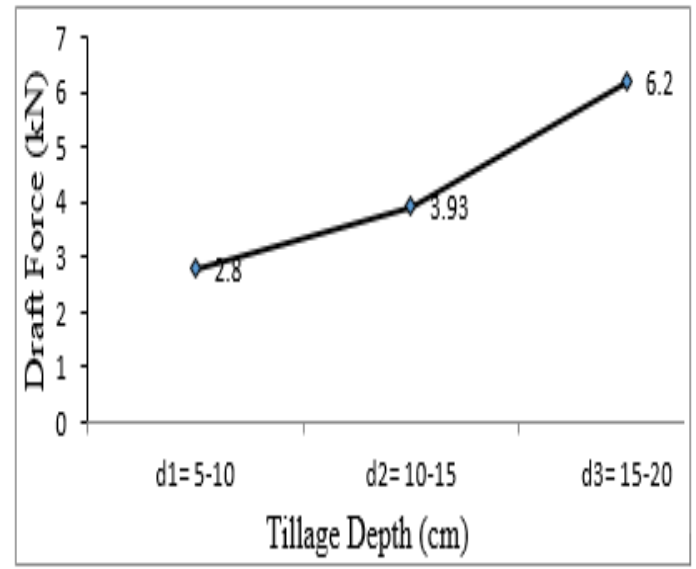

Fig 2: Effect of Tillage Depth on Draft of Disc Plough at Tractor Speed $\mathrm{S} 1=5.4 \mathrm{~km} / \mathrm{hr}(1.5 \mathrm{~m} / \mathrm{s})$

Figure 3 illustrates the effect of speed and tillage depth on draft of disc harrow in Samaru loamy soil. There is slight increase in draft as the speed increases with approximately linear relation at each of the three tillage depths considered: at $5-10 \mathrm{~cm}$. Draft increase by $15 \%$ when speed increase from $S_{1}$ to $S_{2}$ and $13.04 \%$ from $S_{2}$ to $S_{3}$, while at $15-20 \mathrm{~cm}$ depth, draft increase by $3.03 \%$ from $S_{1}$ to $S_{2}$ and $5.88 \%$ from $S_{2}$ to $S_{3}$. The draft increase with increase in tillage depths at each of the three speeds of tractor $(5.4 \mathrm{~km} / \mathrm{hr}, 7.2 \mathrm{~km} / \mathrm{hr}$, and 
$9 \mathrm{~km} / \mathrm{hr}$ ). However, the draft required with disc plough was about $200 \%$ times that of disc harrow when speed or tillage depth increase. When harrowing with disc harrow in Samaru loamy soil, at $5-10 \mathrm{~cm}$ depth of tillage, the speed (S) influenced the draft (D) of disc harrow in Samaru loamy Soil.

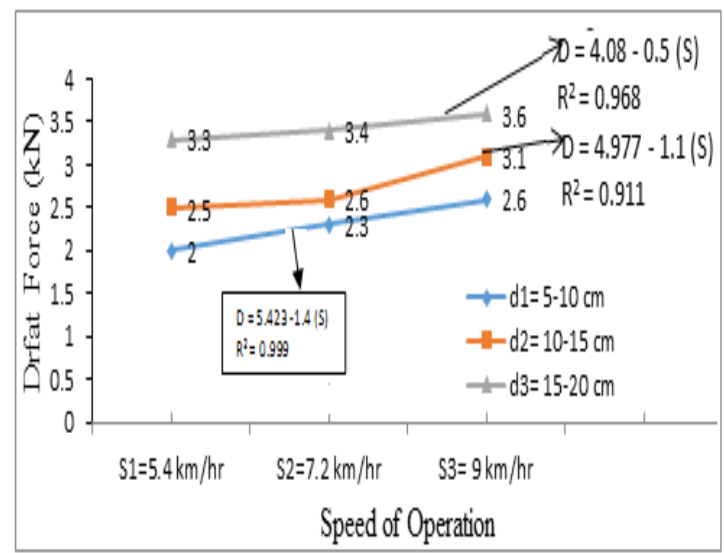

Fig 3: Effect of Speed on Draft of Disc Harrow at Various Tillage Depths in Samaru loamy Soil

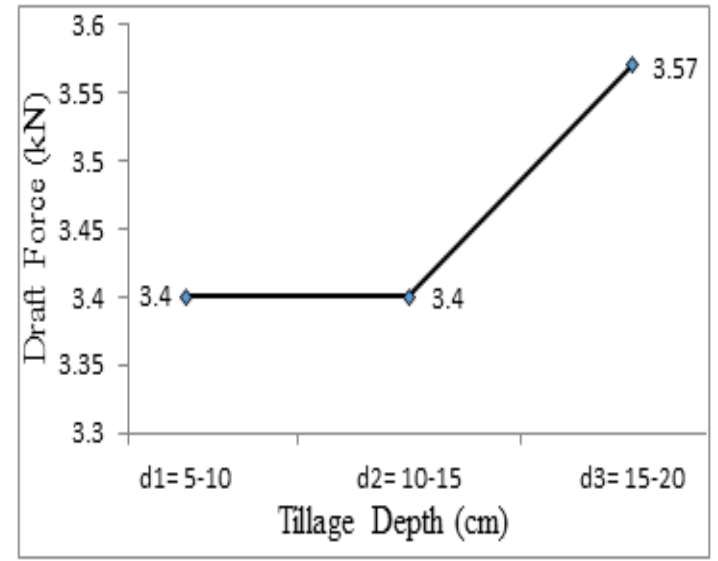

Fig 4: Effect of Tillage Depth on Draft of Disc Harrow at Speed $\mathrm{S} 1=5.4 \mathrm{~km} / \mathrm{hr}$ in Samaru loam soil

Tillage depth effect on draft of disc harrow was different from that of disc plough. It could be seen in Figure 4 that the draft requirement of disc harrow is the same for depths $d_{1}(5-10 \mathrm{~cm})$ and $d_{2}(10-15 \mathrm{~cm})$ and increase positively when the depth increase from $15-20 \mathrm{~cm}\left(\mathrm{~d}_{3}\right)$. This may be caused by the change in bulk density from $1.63 \mathrm{~g} / \mathrm{cm}^{3}$ at $\mathrm{d}_{2}$ to $1.77 \mathrm{~g} / \mathrm{cm}^{3}$ at $\mathrm{d}_{3}$ which translates to the increase in compaction of the soil at deeper layers, thereby requiring greater force to break and cut lumps and clods of the compacted soil in such deeper profile. The speed and tillage depth affect mouldboard ridger quite differently from the discs plough and harrow. Figure 5 shows that there was decrease in draft of mouldboard ridger as the speed increase and the relation was less linear than that of the other two implements, approaching parabolic: at $d_{1}$, draft decrease by $27.57 \%$ from $S_{1}$ to $S_{2}$ and increases by $12.25 \%$ from $S_{2}$ to $S_{3}$. This may be because, there is significant difference between the bottom shape of mouldboard (sliding bottoms) and discs (rotating) implements and the mode of operation, where mouldboard ridger operates by shearing, discs operates by rolling action.

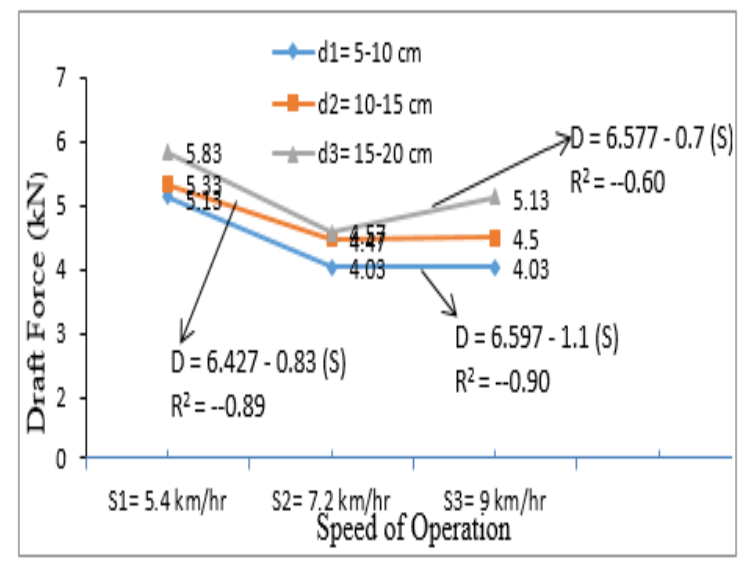

Fig 5: Effect of Speed on Draft of Mouldboard Ridger at Various Tillage Depths in Samaru loamy soil

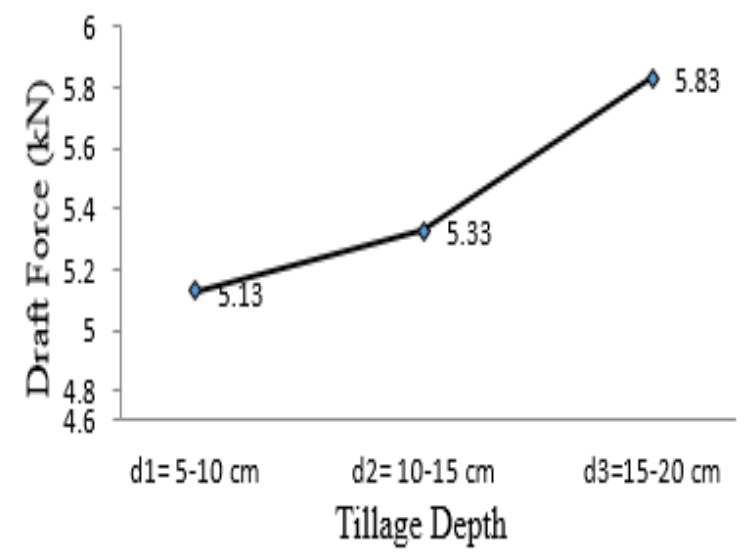

Fig 6: Effect of Tillage Depth on Draft of Mouldboard Ridger at Speed 'S1 $=5.4 \mathrm{~km} / \mathrm{hr}$ '

The draft requirement of mouldboard plough is more than that of disc harrow with about $6.00 \%$ and less than that of disc plough with about $6.70 \%$. Tillage depth affect draft force requirement of mouldboard ridger in opposite sense to that of speed (Figure 6). There is increase in draft of mouldboard ridger with increase in tillage depth and bulk density as more soil is lifted up from deeper layers. The analysis of variance (ANOVA) in Table 2, shows that, there is no significant difference between replicates, but there is significant difference between the three implements $(p \leq 0.01)$ as well as between the three different speeds $(\mathrm{p} \leq 0.01)$. Similarly, there is significant difference between the three tillage depths considered $(p \leq 0.01)$. Therefore, it could be seen that the experimental data 
obtained is of optimum accuracy with the highest coefficient of variation as $5.83 \%$ (least accurate data) obtained at treatment $\mathrm{T}_{1}$ (with disc plough at speed 5.4 $\mathrm{km} / \mathrm{h}$ and $5-10 \mathrm{~cm}$ tillage depth) and least coefficient of variation of $0.81 \%$ (most accurate data) obtained at treatment $\mathrm{T}_{21}$ (with mouldboard ridger at $5.4 \mathrm{~km} / \mathrm{h}$ and $15-20 \mathrm{~cm}$ depth of tillage).

\begin{tabular}{|c|c|c|c|c|c|}
\hline Source of Variation & $\begin{array}{l}\text { Degree } \\
\text { of } \\
\text { Freedom }\end{array}$ & $\begin{array}{l}\text { Sum of } \\
\text { Squares }\end{array}$ & $\begin{array}{l}\text { Mean Sum } \\
\text { of Squares }\end{array}$ & $\begin{array}{l}\text { F- } \\
\text { calculated }\end{array}$ & $\begin{array}{l}\text { F-tabulated (by } \\
\text { interpolation at } 1 \% \\
\text { probability level) }\end{array}$ \\
\hline $\begin{array}{l}\text { Replicates (r) } \\
\text { Implement Type (I) } \\
\text { Speed of Operation (S) }\end{array}$ & 2 & 0.2276 & 0.1138 & 2.229 & $5.0696(\mathrm{NS})$ \\
\hline $\begin{array}{l}\text { Depth of Tillage (d) } \\
\text { I×S } \\
\text { Ixd }\end{array}$ & 2 & 153.4086 & 76.7043 & 1502.474 & $5.0696(\mathrm{SD})$ \\
\hline $\begin{array}{l}\mathrm{S} \times \mathrm{d} \\
\mathrm{I} \times \mathrm{S} \times \mathrm{d}\end{array}$ & 2 & 4.6810 & 2.3405 & 45.845 & $5.0696(\mathrm{SD})$ \\
\hline $\begin{array}{l}\text { Error } \\
\text { Total }\end{array}$ & $\begin{array}{l}2 \\
4 \\
4 \\
4 \\
8 \\
52 \\
80\end{array}$ & $\begin{array}{l}29.6279 \\
63.324 \\
20.5029 \\
1.7217 \\
4.18723635 \\
2.6547 \\
280.3356\end{array}$ & $\begin{array}{l}14.81395 \\
15.831 \\
5.125725 \\
0.430425 \\
0.523404 \\
0.051052\end{array}$ & $\begin{array}{l}290.174 \\
310.096 \\
100.402 \\
8.431 \\
10.252\end{array}$ & $\begin{array}{l}5.0696(\mathrm{SD}) \\
3.7116(\mathrm{SD}) \\
3.7116(\mathrm{SD}) \\
3.7116(\mathrm{SD}) \\
2.898(\mathrm{SD})\end{array}$ \\
\hline
\end{tabular}

The multiple comparison tests performed using least significant difference (LSD) which was found to be

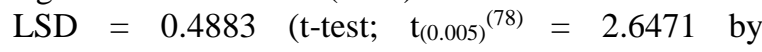
interpolation) between the implements, speeds and tillage depths highlighted that, there is significant difference between all the combinations of means of implements $(\mathrm{p} \leq 0.01)$, there is no significant difference between speeds $S_{2}(7.2 \mathrm{~km} / \mathrm{hr})$ and $S_{3}(9.0 \mathrm{~km} / \mathrm{hr})$ or there mean difference $<$ LSD (Tillage operations with these implement at 7.2-9.0 $\mathrm{km} / \mathrm{hr}$ speed is economical, because draft is neither inadequate nor wasted at these speeds), and there is significant difference between the other speeds combinations, and also there is significant difference between all the combinations of means of tillage depths (mean difference $>$ LSD).

Conclusion: Effects of speed on draft of three tillage implements were studied. The best speed for operation with these implements is $9 \mathrm{~km} / \mathrm{h}$ for optimum production and to conserve energy. Spring Dynamometer of $20 \mathrm{kN}$ capacity was used in conjunction with two Eicher (5660) tractors in measuring the draft requirements of the implements. The study established that increase in speed results in increase in the draft force required to power the implement while ploughing to about $79.9 \%$ at $10-15$ $\mathrm{cm}$ depth and $64.3 \%$ at $5-10 \mathrm{~cm}$ depth when speed increased from $5.4-7.2 \mathrm{~km} / \mathrm{hr}$ ).

\section{REFERENCES}

Abdallah, NO; Mysara, AM; Elnogomi, OA; Abbas, ER; Abualgasim, A (2017). Performance Evaluation Of Giad Chisel Plow Cp007 Under
Different Type Of Soils. Inter. J. Sci. Eng. Res. 8 (3): 12-73

ABU (2018). ABU Zaria Official Website. Retrieved June 10, 2018, from ABU Zaria: www.abu.edu.ng, pp. 1-2.

Agrimoon. (2016). Farm Power and Machinery, ICAR e-course. Retrieved December 12, 2016, from AGRIMoon: www.agrimoon.com, pp.48-55

ASAE (2000). Agricultural Machinery Management Data. ASAE STANDARDS. 2950 Niles Rd, St. Joseph, United States of America: ASAE, pp. 3-4

Chandrasekaran, B; Annadurai, K; Somasundaran, E (2010). A Textbook of Agronomy. New Delhi: New Age International Publishers, pp.1-2\&287295

Hunt, DR (1979). Farm Power and Machinery Management (4th ed.). Iowa: Iowa state university press, pp. 120-127

Kawuyo, UA (2011). Mathematical Modelling of Draught Characteristics of Selected AnimalDrawn Implements on the Upland Soils of Samaru, Nigeria. Ahmadu Bello University, Agricultural and Bio-resources Engineering. Zaria: Unpublished Phd Thesis, pp.1-2, 7\&51.

Majid, R; Iman, N; Jabak, J; Seyyed, ME; Mahmud, F (2013). Effect of Soil Moisture Content, Tillage Depth and Operation Speed on Draft of 
Mouldboard Plow. Middle-East J. Sci. Res., 16 (2): 245-249.

Naderloo, L; Alimadani, R; Akram, A; Javadikia, P; Zeinali, HK (2014). Tillage Depth and Forward Speed Effects on Draft of Three Primary Tillage Implements in Clay Soil. Food, Agric. Environ. 7 (3\&4), 382-385.

Nkakini, SO (2015). Draught Force Requirements of Disc Plough at Various Tractor Forward Speeds in Loamy Sand Soil, During Ploughing. Inter. J. Adv. Res. Eng. Technol., 6, 52-68.
Omofunmi, OA; Tanimola, OA; Oyekunle, OO (2016). To Assess the Impact of Disc Plough Weight and Draught on Physical Properties of Sandy Loamy Soil. J. Agric. Vet. Sci. 2(9), 44-50

USDA (1984). Plowing with Mouldboard Plow. Farmers' Bulletin No. 1690 ( By Wallase, Ashby and Glaves, A. H.) . United States of America: U. S. Department of Agriculture, pp.2-5. 